\title{
Social media in tourism: Establishing factors influencing attitudes towards the usage of social networking sites for trip organisation
}

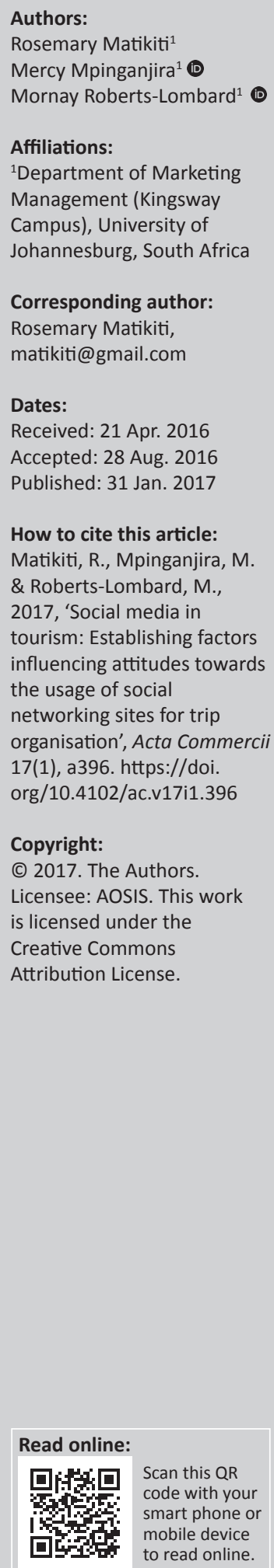

Purpose: The main aim of this study was to determine the attitude towards the use of social networking sites (SNSs) for trip organisation and its precursors.

Problem investigated: Tourism organisations and destination policy makers need to understand factors that influence tourist use of SNSs for trip organisation in order for them to be able to effectively utilise SNSs.

Methodology: The methodological approach followed was exploratory and quantitative in nature. Data were collected from a total of 340 respondents using a structured questionnaire. Structural equation modelling through the use of Partial Least Squares was for data analysis.

Findings and implications: The results show that attitude towards the use of SNSs for trip organisation is affected by perceived benefits, subjective norm and perceived behavioural control, with perceived usefulness having the greatest influence. The implication is that managers of tourism organisations need to ensure that their sites are informative, easy to use and able to safeguard users' online privacy if they are to attract more and loyal users to their sites.

Value of the research: Very little research in the South African context exists with specific reference to how SNSs are being utilised for trip organisation. This article contributes by unravelling factors that influence the use of SNSs for trip organisation.

Conclusion: Perceived usefulness measured by functional benefits and social benefits is the key factor that influences attitude towards the use of SNSs for trip organisation. It is the responsibility of destination marketers to provide all the necessary or valuable information on their SNS accounts, in order to encourage travellers to use SNSs.

\section{Introduction}

Over the last decade, the growth of Internet technologies, especially social media platforms such as social networking sites (SNS) (Facebook, Twitter, MySpace vibe, Pinterest, Instagram), has increased considerably. Bhakuni and Aronkar (2012) as well as Richard and Guppy (2014) observed that the use of social networking sites (hereafter referred to as SNS) grew rapidly from a platform that serves a few people online to a platform that is used by a significant number of Internet users. These sites have evolved from a basic online tool for content sharing to become an important part of the media landscape (Singh, Lehnert \& Bostick 2012:685). Statistics show there were 2.078 billion social media accounts that were active in January 2015 globally, with Facebook leading with a total of 1.4 billion users (Kemp 2015:2; Statista 2015:1). In South Africa, 11.8 million people (22\% of the total population) are on Facebook and the number of people on YouTube and Instagram has increased by 53\% and 65\%, respectively, between August 2014 and August 2015 (South Africa Social Media Landscape 2015:3). Gong (2012:421) pointed out that among the Internet-related technologies, SNSs are the fastest growing.

Unique characteristics of SNS, including their interactive nature, the ability to show videos and pictures and screening and filtering of information by friends, have enabled them to attract large numbers of users across the globe (Lange-Faria \& Elliot 2012). The penetration of mobile devices, particularly smartphones, which provide travellers with the means to connect on-the-go and interact in real time, also made social networking more attractive than any other communication tools (Gong 2012:422). A total of 8.8 million South Africans primarily accessed Facebook in 2015 
through mobile phones such as Android, Blackberry and Windows (South Africa Social Media Landscape 2015:3). The fact that travel information can now be easily accessed through mobile phones and computers has special implications for organisations operating in the tourism industry. A study by Lyu and Wang (2015) revealed that because of the introduction of new Internet technologies (e.g. social media), the number of individuals who use traditional information centres (travel agents and tour operators) to obtain travel information, has dropped by $27.6 \%$ in Korea. They noted that travellers now prefer social media to traditional sources of information (Lyu \& Wang 2015). Therefore, it is important for tourism organisations and tourism policy makers to understand the different factors that influence travellers' use of SNSs when organising a trip. Establishing these factors will go a long way in assisting tourism managers and policy makers to gain knowledge on how best to appeal to users of their SNSs. Currently, TripAdvisor, the leader among travel-related consumer reviews on a SNS (TripAdvisor 2015), serves more than 200 million people, and the application is being downloaded at a rate of 28 times per minute (TripAdvisor 2015). Therefore, TripAdvisor is playing a major role in trip organisation when using search engines (Di Pietro \& Di Virgilio 2012: 62; Greenleigh 2012; Xiang \& Gretzel 2010:181).

Against this background provided, this study aims at contributing to the existing literature on the attitude and perceptions of individuals towards the usage of SNS for trip organisation purposes. The Theory of Planned Behaviour (TPB) model is applied to the study to help explain intentions to use SNS for trip organisation among travellers in Gauteng, South Africa, making the focus of the study novel as most studies on social media are based on samples drawn from western and Asian countries. The current study attempts to extend the TPB model by adding another factor, which is perceived risk (PR). A combination of TPB variables with PR may provide a model that captures extensive elements, which can better explain SNS adoption behaviour by customers in the tourism industry in South Africa. The TPB model is considered suitable for the study because of the fact that it is regarded as one of the most effective models in predicting online technology adoption behaviour among consumers (Jalilvand \& Samiei 2012:593; Quintal, Lee \& Soutar 2010:798; Troung 2009:179; Hsu et al. 2006:890). Therefore, checking the applicability of TPB model in explaining SNS usage from a travel organising perspective (Lopez et al. 2011:642), could assist tourism organisation managers and destination policy makers to have an insight of the factors that affect user acceptance. The study addresses the overall use of social media for trip organisation and is not restricted to a specific SNS.

\section{Problem statement}

South African Tourism has a digital marketing partnership with SNSs such as YouTube, TripAdvisor and Facebook (South African Tourism Review 2015). For example, in 2013, the Cape Town Tourism Board won the Social Media in Travel and Tourism award for the innovative use of online technologies for marketing Cape Town tourism attractions (Cape Town Tourism 2013). This illustrates that the South African tourism industry is using SNSs to attract visitors. Therefore, it is important to determine how individual travellers are utilising SNSs when organising trips in order to improve on the effective utilisation of SNSs. More importantly, tourism organisations have to be aware of the different factors that influence individual traveller use of SNS before, during and after the trip (Lopez et al. 2011:643). Such an understanding remains unclear and requires further investigation.

\section{Main objective}

To determine the factors that influence customers' attitude towards SNSs for trip organisation and the influence of attitude on use intentions.

\section{Secondary objectives}

To examine factors that influence the attitude towards the use of SNSs for trip organisation.

To establish the relative power of factors that influence the attitude towards SNSs.

To establish whether attitude towards SNSs has a direct influence on behavioural intentions to use and to recommend the use of SNS for trip organisation.

To propose and test a conceptual model on precursors of attitude and behavioural intentions towards use of SNS for trip organisation.

\section{Literature review Theoretical background}

Theory of Reasoned Action (TRA) was formed in a bid to determine factors that influences attitude and behaviour (Fishbein \& Ajzen 1975). TRA is centred on the aspect that subjective norm ( $\mathrm{SN}$ ) and attitude towards behaviour are the two factors that affect behavioural intention (Fishbein \& Ajzen 1975:302). TRA has been successfully tested by a number of studies (Abadi \& Nematizadeh 2012; Pelling \& White 2009; Peslak, Ceccucci \& Sendall 2012; Porter \& Donthu 2006) to predict behavioural intention in online technology acceptance. However, despite the applicability of TRA in predicting online technology acceptance in so many fields, the model had some limitations, which were identified by Ajzen (1988). The major limitation of TRA is that it can only be applied successfully if the behaviour in question is under the will of the person. If behaviour is not under the person's will and control, that individual may not perform the behaviour because of other environmental conditions that might intervene (Ajzen 1988). This has led to the formulation of the TPB. 


\section{Theory of planned behaviour}

TPB was proposed by Ajzen (1988). It has an additional factor to those in TRA, perceived behavioural control (PBC). The theory is centred on three kinds of beliefs (attitude, $\mathrm{SN}$ and PBC). PBC means the ability to perform certain behaviour, and it influences the intention to perform the behaviour (Zoonen, Verhoeven \& Elving 2014:166). According to the TPB model, when a person has a positive attitude towards a behaviour and the influence of friends is higher, the individual's conviction that he/she can perform the behaviour increases, thereby strengthening the intention to perform the behaviour as well (Ajzen 1991:187). According to the model, one aspect which is on the centre of human behaviour is intention to perform, and this aspect is influenced by attitude towards behaviour, the amount of pressure received from friends and one's perceived ability to perform the behaviour. Thus, in this study it is postulated that variables in the TPB model, that is, $\mathrm{PBC}$ and $\mathrm{SN}$, significantly influence the attitude towards the use of SNS with regard to travelling.

\section{Social networking sites and trip organisation}

SNSs are defined by Hoffman and Novak (2012:1) 'as webbased applications that permit creation, sharing, manipulation and consumption of user-generated content'. They provide individuals with platforms to create an identity online and present their image (Hollenbeck \& Kaikati 2012:396). There are currently a number of SNSs used by people to chat and share information about their trips, something which was not possible just over a decade ago (Senthil, Prabhu \& Bhuvaneswari 2013:51). The first SNS according to Boyd and Ellison (2007:211), was introduced in 1997, Six degree.com, which allowed users to create a profile and list their friends. This was followed by Friendster.com launched in 2002. After this, there was a wave of SNSs with different focus, for example, LinkedIn (2003) for business, and MySpace (2003), Facebook (2005) and Twitter (2006) for general discussions. WeChat, Pinterest and Instagram are some of the SNSs that have gained momentum in the last three years. As indicated by Gong (2012:422), users of these SNSs are not only passive content consumers but also active content generators and distributors. Given their increasing popularity, SNSs have significantly impacted the way people consume information, socialise, and search for travel information as well as organise trips.

As the uptake of SNSs increases, academic research surrounding the usage of SNSs in tourism is also growing. Di Pietro and Di Virgilio (2012), for example, studied the usage of SNSs on destination choice and discovered that most tourists use SNSs extensively for choosing holiday accommodation. Xiang and Gretzel (2010:184) indicate that SNSs constitute a considerable part of online tourist domain and play a vital role when people are organising trips. In line with the TPB, this study investigates the influence or perceived usefulness (PU), SN and PBC on attitude towards the use of SNS for trip organisation. It also looks at the influence of PR on attitude, as well as the influence of attitude on behavioural intentions.

\section{Attitude, its precursors and outcomes}

Attitude towards behaviour is described 'as the extent to which an individual has a favourable or unfavourable assessment of the behaviour in question' (Ajzen 1991:188). If the attitude towards behaviour is positive, the individual's desire to perform that particular behaviour increases (Ajzen 1991:188). Attitudes can be described as a person's overall assessment of performing a particular behaviour (Celik \& Yilmaz 2011:158). The following discussion refers to factors that may help explain attitude towards the use of SNS for trip organisation.

\section{Precursors of attitude}

\section{Perceived usefulness}

Perceived usefulness (PU) is defined as 'the extent to which a person is convinced that using a particular technology would improve their performance' (Henderson \& Divett 2003:394). In the case of this study, PU was viewed as the benefits derived from using SNSs for trip organisation. These benefits according to Lopez et al. (2011) are different and constantly change such that it is not easy to establish them because of the heterogeneous nature of travellers and their ability to use these SNSs. Lopez et al. (2011:643) categorise these benefits into three dimensions, which are functional benefits, social benefits and hedonic benefits. In their study, Lopez et al. (2011) concluded that functional and social benefits significantly influence attitude towards the usage of social media when organising trips. For this study, two types of benefits, functional benefits and social benefits are assessed, following what has been proposed in e-commerce literature (Chung \& Buhalis 2008; Gretzel \& Yoo 2008; Jeong 2008; Lopez et al. 2011). Chung and Buhalis (2008) and Sigala (2010) opine that functional and social benefits play an important role in determining the use of SNSs. It is posited in this study that SNSs perceived that usefulness, which is divided into functional and social benefits, can influence the attitude towards the usage of SNSs for trip organisation. To ascertain this, the following hypothesis was formulated:

H1: Perceived usefulness positively influences the attitude towards the use of social networking sites for trip organisation.

\section{Subjective norm}

Subjective norm (SN) is described 'as the perceived social pressure to perform or not to perform behaviour' (Ajzen 1991:188). TPB views influence or pressure from friends and social groups to be important when one is highly motivated to comply with the exerted pressure (Zoonen et al. 2014:166). The effect of SN on behavioural intention has been supported by some previous studies. Zhou (2011) concluded that SN impacts on online community users' participation intention, and Akman (2014) concluded that SN has an effect on 
behavioural intention to use social media. Lopez-Nicolas, Molina-Castillo and Bouwman (2008) also found the effect of $\mathrm{SN}$ on users' intention to play online games. Taking cognisance of the argument in TPB that attitude is related to behavioural intention, this study thus hypothesised that:

H2: Subjective norm positively influences the attitude towards the use of social networking sites for trip organisation.

\section{Perceived risk}

Perceived risk (PR) has been defined by Bauer (1967:191) as 'a combination of the uncertainty and seriousness of the outcome involved'. In support of this, Peter and Ryan (1976:185) defined PR 'as the expectation of losses associated with purchase and acts as deterrents to purchase behaviour'. PR as proposed by Cunningham (1976) can be decomposed into subfacets (a) performance risk and (b) psychosocial risk. They further decomposed PR into six categories which are: (a) performance, (b) financial, (c) safety/privacy, (d) social, (e) time, and (d) psychological loss. In 1971, Roselius classified PR into five groups which are, time loss, psychological loss, financial loss, physical loss and performance loss. Physical risk and financial risk were not included in this study as they are deemed not applicable to SNSs. Earlier studies (Mannuka \& Jarvi 2014; Skarmeas \& Robson 2008) found that PR affects how consumers perceive value, and thus negatively affects perceived benefits. PR also reduces the expected benefits of a particular outcome of a decision-making process and consequently reduces the behavioural intention (Skarmeas \& Robson 2008:180). Thus in this study, PR comprises of (a) social risk, (b) privacy risk and (c) time risk.

Social risk is defined in this study as the potential loss in one's set of friends as a result of using SNSs, for example, not fitting in the set of your friends. Time risk is defined as the time wasted through searching and learning how to use social networks, which could be spent productively when using other means of trip organisation. 'Privacy risk refers to the potential loss of control of personal information', for example, if an individual's personal information is used without their knowledge (Mannuka \& Jarvi 2014:223). This study posits that PR has negative effects on PU and attitude towards SNSs. The following hypotheses were thus formulated:

H3: Perceived risk has a negative influence on the perceived usefulness of social networking sites for trip organisation.

H4: Perceived risk negatively influences the attitude towards the use of social networking sites for trip organisation.

\section{Perceived behavioural control}

$\mathrm{PBC}$ is essentially the same idea as self-efficacy, which is the measure of a person's perception of their ability to complete a duty (Yzer 2012:103), in this case, the ability to use SNSs to organise a trip. PBC, according to Yzer (2012:103), incorporates two specific aspects, which are perceived ability (which is the extent to which one is convinced that they can carry out a task or perform the behaviour) and perceived autonomy (the extent to which one is convinced that he or she can control the actual behaviour). This study looks at PBC in the context of confidence and certainty of being able to use SNSs when organising trips. Studies by Baker and White (2010), Hocevar, Flanagin and Metzeger (2014) as well as Leng et al. (2011) have found that PBC (self-efficacy) exerts significant positive influence attitude towards the use of SNSs. Accordingly, it is hypothesised in this study that:

H5: Perceived behavioural control positively influences the attitude towards the use of social networking sites for trip organisation.

\section{Behavioural intentions and its precursors}

Behavioural intention describe those factors that motivate someone to perform certain behaviour and indicates one's desire to try or how they seriously attempt to perform that particular task (Ajzen 1991:181). In this study, intention to use defines the willingness to use SNSs for trip organisation, and intention to recommend refers to the objective to advise others to use social networks when organising trips.

\section{Perceived behavioural control}

The effect of $\mathrm{PBC}$ on intention has been examined in various studies. A study by Alam and Sayuti (2011) found that PBC influences the intention to purchase halal food. Martin, Ramamonjiarivelo and Martin (2011) found that PBC is an important factor that influences travel intention. However, Sentosa and Nik Mat (2012) examined the applicability of TPB in Internet purchase behaviour and concluded that PBC is not an important determinant of behavioural intention. It is assumed in this study that PBC can affect one's intention to use SNSs when organising trips. The following hypothesis is therefore put forward:

H6: Perceived behavioural control has a significant effect on the intention to use social networking sites for trip organisation.

\section{Attitude}

Rauniar et al. (2014) examined the applicability of Technology Acceptance Model (TAM) in explaining social media use and concluded that attitude affects the intention to use SNSs. For the purpose of this study, TAM is defined 'as a causal model which explains factors that affect behavioural intentions in the usage of new information technologies' (Davis 1989:323). Wei et al. (2015) examined the intention of users to continue using SNSs and concluded that attitude can positively influence the intention to continue using a SNS. Dennis et al. (2009) formulated a conceptual model to explain e-consumer behaviour and concluded that purchase intention is positively influenced by positive attitude. It is assumed in this study that attitude has a positive impact not only on intentions to use but also on intentions to recommend others to use SNSs. The following hypotheses are formulated to ascertain the influence of attitude on the intention to use SNSs and the intention to recommend others to use SNSs: 
H7: Attitude towards the use of social networking sites has a significant positive impact on the intention to use social networking sites for trip organisation.

H8: Attitude towards the use of social networking sites has a significant positive impact on the intention to recommend others to use social networking sites for trip organisation.

The proposed model for this study depicting all the formulated hypotheses is presented in Figure 1.

\section{Research methodology Research design and sampling}

The study used an exploratory research design that was quantitative in nature. The objective of exploratory research is to determine important or key variables and it also considers the nature of certain relationships (Zikmund 1984:6). This study seeks to establish key factors that influence attitude towards the use of SNSs; hence, the exploratory research design was chosen. A cross-sectional approach was used to collect data by means of questionnaires where data were collected from the sample on one occasion only. According to Bhattacherjee (2012:18), cross-sectional design can be used to provide data for an exploratory enquiry. The target population for this study was all travellers in the city of Johannesburg in South Africa who are aware of one or more travel-related SNSs and those who use SNSs for trip arrangements. The sample was heterogeneous and consisted of both users and non-users of travel-related SNSs. The study focused on both business travellers and leisure travellers. Respondents who met this criterion were selected to complete the questionnaire. In order to select the sample for this study, a convenience sampling technique was used where only those individuals who could be easily accessed were asked to answer the questionnaire. The convenient sampling technique involves the selection of the most accessible subjects (Marshal 1996:523). The questionnaire was administered by trained fieldworkers. A total of 340 questionnaires were returned and used for analysis.

\section{Measurement development}

To ensure validity of measurement items used for this study, items were borrowed from existing measures

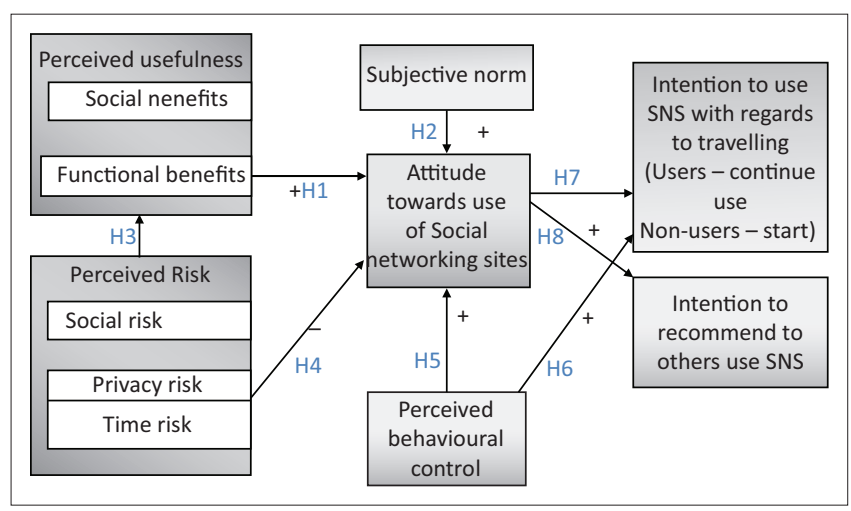

Source: Researcher's own construct

FIGURE 1: Proposed research model.
(Quintal et al. 2010). The questionnaire items were adopted from existing literature (see Appendix 1, Table 1-A1), but adapted to fit the use of SNSs for trip organisation. The study used a five-point Likert scale to ensure validity because the studies in which the questionnaire items were adopted also used a five-point Likert scale. The scales were ranging from strongly disagree to strongly agree, except for those measures that solicited demographic information. The survey instrument was pretested on 20 travellers (users and non-users who are aware of any travel SNSs). The pretesting was done mainly to check the ease of understanding of the questions by respondents. After the pretests, the questions were so that all respondents can understand the requirements of the questionnaire.

For the analysis of data, SPSS Version 21 was used. The reliability and validity of the constructs were tested using confirmatory factor analysis. Structural Equation Modelling through the use of Partial Least Squares (PLS) was used for hypotheses testing. Table 1 provides the background information of the respondents.

The other SNSs indicated by respondents were Google, followed by Pinterest.

\section{Analysis and results}

The PLS technique was used because it is suitable for examining compound relationships, for example, where there are large numbers of variables by avoiding inadmissible solutions and factor indeterminacy (Chin 1998:8). The PLS technique also allows the testing of hypotheses simultaneously, even if there are measures with single and multiple constructs (Fornell \& Bookstein 1982:43).

\section{Measurement model}

The model included 36 items describing 10 latent constructs: attitude, PBC, functional benefits, social benefits, time risk, social risk, privacy risk, SN, intention to use SNSs and intention to recommend others to use SNSs. The obtained chi-square

TABLE 1: Respondents' background information.

\begin{tabular}{lccc}
\hline Variables & Category & $\begin{array}{c}\text { No. of } \\
\text { respondents }\end{array}$ & $\begin{array}{c}\text { Frequency } \\
(\mathbf{\%})\end{array}$ \\
\hline Gender & Male & 181 & 53.2 \\
& Female & 159 & 46.8 \\
Age, years & $17-22$ & 144 & 42.4 \\
& $23-28$ & 106 & 31.2 \\
& $29-34$ & 51 & 15.0 \\
& $35-40$ & 26 & 7.6 \\
Use of SNS for trip organisation & Over 40 & 13 & 3.8 \\
Type of SNS used for trip organisation & Yes & 242 & 71.2 \\
& Facebook & 114 & 28.8 \\
& TripAdvisor & 53 & 21.9 \\
& Twitter & 34 & 14.0 \\
& MySpace & 3 & 1.2 \\
& Other & 38 & 15.7 \\
\hline
\end{tabular}

Source: Researcher's own compilation from descriptive analysis results SNS, social networking sites. 
value for the measurement model was 694.29 with $332 \mathrm{DF}$ and a $p$-value of 0.068 . The normed chi-square value $\chi^{2} /(\mathrm{df}=332)$ was thus 2.38. The acceptable value of normed chi-square to show fit according to Schumacker and Lomax (2004:238) was less than 5. Other fit statistics showed good fit. The Root Mean Square Error of Approximation (RMSEA) was 0.04, TuckerLewis Index (TLI) was 0.95, and Goodness of Fit Index (GFI) was 0.92, while Normative Fit Index (NFI) was 0.96.

For a model to be regarded as fit, the TLI and the NFI need to be 0.95 or more than this figure, and the RMSEA has to be below 0.6, while the GFI needs to be 0.9 or more (Hu \& Bentler 1999:37; Baumgartner \& Hombur 1996:153). Fit outputs contain a large array of model fit, but this study reports only the commonly reported fit statistics.

Cronbach alpha was calculated in order to ascertain scale reliability. Constructs are considered reliable when the reliability coefficient is 0.7 or greater (Hu \& Bentler 1999:37). Results in Table 2 show that all constructs used in this study had reliability of above 0.70 .

TABLE 2: Confirmatory factor analysis results.

\begin{tabular}{|c|c|c|c|c|c|c|c|}
\hline Factor/Item & Standard loading & $t$ & Cronbach's $\alpha$ & CR & AVE & MSV & ASV \\
\hline Social risk & - & - & 0.82 & 0.80 & 0.62 & 0.55 & 0.23 \\
\hline SR1 & 0.79 & 18.89 & - & - & - & - & - \\
\hline SR2 & 0.68 & 16.91 & - & - & - & - & - \\
\hline SR3 & 0.81 & 19.82 & - & - & - & - & - \\
\hline Time risk & - & - & 0.91 & 0.91 & 0.76 & 0.58 & 0.25 \\
\hline TR1 & 0.90 & 20.54 & - & - & - & - & - \\
\hline TR2 & 0.86 & 19.67 & - & - & - & - & - \\
\hline TR3 & 0.91 & 20.93 & - & - & - & - & - \\
\hline Privacy risk & - & - & 0.78 & 0.76 & 0.61 & 0.31 & 0.06 \\
\hline PR1 & 0.68 & 17.54 & - & - & - & - & - \\
\hline PR2 & 0.78 & 21.37 & - & - & - & - & - \\
\hline PR3 & 0.80 & 21.93 & - & - & - & - & - \\
\hline Functional benefits & - & - & 0.83 & 0.80 & 0.73 & 0.57 & 0.25 \\
\hline FB1 & 0.81 & 22.37 & - & - & - & - & - \\
\hline FB2 & 0.79 & 20.56 & - & - & - & - & - \\
\hline FB3 & 0.78 & 19.36 & - & - & - & - & - \\
\hline Social benefits & - & - & 0.89 & 0.78 & 0.68 & 0.33 & 0.09 \\
\hline SB1 & 0.67 & 14.83 & - & - & - & - & - \\
\hline SB2 & 0.78 & 21.24 & - & - & - & - & - \\
\hline SB3 & 0.88 & 22.01 & - & - & - & - & - \\
\hline SB4 & 0.80 & 20.63 & - & - & - & - & - \\
\hline Subjective norm & - & - & 0.91 & 0.87 & 0.71 & 0.51 & 0.19 \\
\hline SN1 & 0.81 & 22.37 & - & - & - & - & - \\
\hline SN2 & 0.90 & 25.02 & - & - & - & - & - \\
\hline SN3 & 0.75 & 20.04 & - & - & - & - & - \\
\hline Perceived BC & - & - & 0.75 & 0.72 & 0.63 & 0.29 & 0.05 \\
\hline PBC1 & 0.76 & 20.62 & - & - & - & - & - \\
\hline PBC2 & 0.65 & 16.95 & - & - & - & - & - \\
\hline PBC3 & 0.70 & 18.39 & - & - & - & - & - \\
\hline PBC4 & 0.72 & 17.56 & - & - & - & - & - \\
\hline PBC5 & 0.75 & 20.78 & - & - & - & - & - \\
\hline Attitude & - & - & 0.86 & 0.73 & 0.64 & 0.29 & 0.05 \\
\hline ATT1 & 0.78 & 18.64 & - & - & - & - & - \\
\hline ATT2 & 0.86 & 25.46 & - & - & - & - & - \\
\hline ATT3 & 0.80 & 18.21 & - & - & - & - & - \\
\hline ATT4 & 0.75 & 17.38 & - & - & - & - & - \\
\hline ATT5 & 0.81 & - & - & - & - & - & - \\
\hline Intention to use & - & - & 0.91 & 0.90 & 0.82 & 0.59 & 0.21 \\
\hline INT1 & 0.81 & 26.01 & - & - & - & - & - \\
\hline INT2 & 0.79 & 25.67 & - & - & - & - & - \\
\hline INT3 & 0.83 & 33.23 & - & - & - & - & - \\
\hline INT4 & 0.78 & 21.89 & - & - & - & - & - \\
\hline $\begin{array}{l}\text { Intention to } \\
\text { recommend }\end{array}$ & - & - & 0.84 & 0.84 & 0.72 & 56 & 0.24 \\
\hline INTR1 & 0.81 & 19.58 & - & - & - & - & - \\
\hline INTR2 & 0.67 & 15.84 & - & - & - & - & - \\
\hline INTR3 & 0.69 & 18.66 & - & - & - & - & - \\
\hline
\end{tabular}

Source: Extracted form SPSS statistical analysis results

$\mathrm{CR}$, composite reliability; AVE, average variance extracted; MSV, maximum shared squared variance; ASV, average squared variance; PBC, perceived behavioural control. 
The measurement model's convergent validity was tested using factor loading, composite reliability (CR) and Average Variance Extracted (AVE). Convergent validity was demonstrated because all the items in Table 2 displayed a factor loading, which is above 0.50 (Hair et al. 2010). CR results on Table 2 show that all the items displayed values which exceed 0.70, demonstrating convergent validity (Hair et al. 2010). The values of AVE for all the items as shown in Table 2 exceed 0.50, showing good convergent validity (Fornell \& Larcker 1981:45).

The model's discriminant validity was tested using the Maximum Shared Squared Variance (MSV), the Average Squared Variance (ASV) and the square root of AVE values. According to Hair et al. (2010:86) and Fornell and Larcker (1981:46), the AVE values should be greater than MSV and ASV values. The square root of AVE should be greater than interconstruct correlations and the item to construct correlation should be stronger than the correlation with other constructs. MSV and ASV values in Table 2 show that all items are less than AVE values, and Table 3 also shows that the square roots (shown as the bolded diagonal figures) are greater than interconstruct correlations. The cross-item correlation results in Appendix 1, Table 2-A1 also demonstrate discriminant validity as the item-to-construct correlation shows a stronger correlation (bolded figures in Appendix 1, Table2-A1) to each other than to contruct-to-contruct correlation.

\section{Structural model}

The results of PLS path coefficients are shown in Figure 2. The obtained results in Figure 2 show that all the paths are statistically significant. According to the results, $18 \%$ of the difference in PU is revealed by the structural model, $40 \%$ of the difference in attitude is revealed by the structural model, $22 \%$ of the difference in intention to use is revealed by the structural model and $18 \%$ of the difference intention to recommend is explained by the structural model. This shows that the model offers a good explanation of the use of online sites for trip organising.

The PLS results in Figure 2 report that PR $(b=-0.12, p<0.05)$ negatively affects PU, thereby reducing its PU. PR $(b=-0.28$, $p<0.01$ ) negatively influences attitude towards the use of SNSs for trip organisation. Hypotheses 3 and 4 are therefore supported. The results also show that PU $(b=37, p<0.001)$, SN $(b=15, p<0.01)$ and PBC $(b=28, p<0.01)$ positively influence the attitude towards the use of SNSs. Hypotheses 1 , 2 and 5 are thus supported.

PBC ( $b=18, p<0.01)$ was found to have a significant influence on intention to use SNSs, implying that hypothesis 6 is supported. The results also indicate that attitude ( $b=42, p<0.001$ ) significantly influences both the intention to use SNSs and to recommend others to use SNSs for trip organisation $(b=13, p<0.05)$. The use of SNSs thus supports hypotheses 7 and 8 . Therefore, the results provide evidence for the support of the proposed model. Part of the model was hierarchical because some factors (PU and PR) were made up of various dimensions (Wetzels, Odekerken-schroder \& Van Oppen 2009). The first two factors included in this study, PU and PR, have dimensions. Two dimensions exist for PU (functional and social benefits) and three dimensions for PR (privacy, social and time risk). Thus, the importance of each dimension in building the second-order constructs was also considered. From Figure 2, it is deduced that privacy risk (0.89) displays a value, which is statistically different from the other dimensions (social and time risk); therefore, privacy risk is more important in producing the second-order construct PR. Functional benefits (0.90) also display a value, which is statistically different from social benefits (0.57), and is therefore more important in building the second-order construct, PU. Against this background, Table 4 provides a summary of the hypotheses testing.

\section{Discussion and conclusion}

The use of SNSs for trip organising is increasing daily (Lange-Faria \& Elliot 2012:197) primarily because it provides an ideal platform for users to interact and share their travel experiences by posting comments, sharing pictures and videos. The model proposed in this study highlights that PR negatively impacts both PU and the attitude towards the use of SNSs for trip organisation. This conclusion concurs with the study by Featherman and Pavlou (2003), which postulated that PR adversely affects online sites' PU. However, the influence of PR on attitude was found to be greater than that on PU. This shows that if people perceive that there is a risk associated with using some SNSs, they develop a negative attitude towards the sites. The model

TABLE 3: Descriptive statistics, correlations and square root of AVE.

\begin{tabular}{|c|c|c|c|c|c|c|c|c|c|c|c|c|}
\hline Construct & Mean & SD & 1 & 2 & 3 & 4 & 5 & 6 & 7 & 8 & 9 & 10 \\
\hline 1 Social risk & 6.13 & 1.91 & 0.79 & - & - & - & - & - & - & - & - & - \\
\hline 2 Time risk & 5.12 & 1.10 & 0.29 & 0.87 & - & - & - & - & - & - & - & - \\
\hline 3 Privacy risk & 5.62 & 1.08 & 0.21 & 0.34 & 0.78 & - & - & - & - & - & - & - \\
\hline 4 Functional benefits & 3.12 & 1.34 & -13 & -01 & -32 & 0.85 & - & - & - & - & - & - \\
\hline 5 Social benefits & 4.86 & 1.22 & -12 & 0.04 & -13 & 0.23 & 0.82 & - & - & - & - & - \\
\hline 6 Subject norm & 3.21 & 1.37 & 0.01 & 0.15 & 00 & 0.19 & 0.14 & 0.84 & - & - & - & - \\
\hline 8 Attitude & 3.19 & 1.27 & -23 & -07 & -34 & 0.58 & 0.48 & 0.52 & 0.60 & 0.88 & - & - \\
\hline 9 Intention to use & 5.99 & 1.06 & -11 & -04 & -11 & 0.56 & 0.47 & 0.42 & 0.28 & 0.27 & 0.91 & - \\
\hline 10 Intention to recommend & 4.56 & 1.19 & -09 & -01 & -02 & 0.43 & 0.13 & 0.31 & 0.21 & 0.12 & 0.39 & 0.85 \\
\hline
\end{tabular}

Source: Extracted from SPSS statistical analysis results

SD, standard deviation. The square root of AVE (Average Variance Extracted) values is represented diagonally (in bold). 


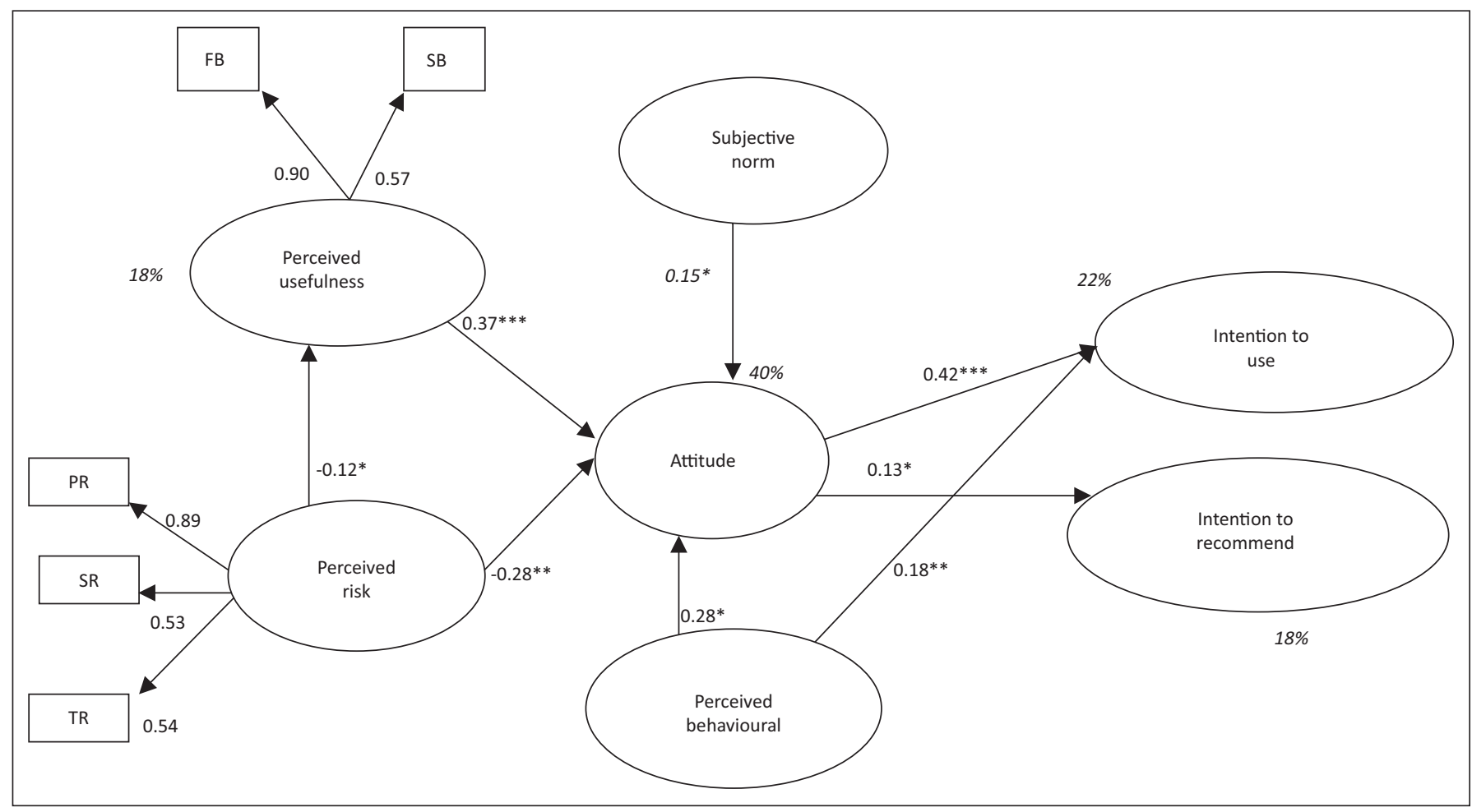

Source: Extracted from SEM results

$*, p<0.05 ; * *, p<0.01 ; * * *, p<0.001$.

FIGURE 2: Partial Least Squares (PLS) results.

\section{TABLE 4: Summary of hypotheses testing.}

\section{Hypotheses}

H1: Perceived usefulness positively influences the attitude towards the use of social networking sites for trip organisation

H2: Subjective norm positively influences the attitude towards the use social networking sites for trip organisation

also illustrates that among the facets of risk (time, social and privacy risk) used for this study, privacy risk (0.89) displayed a value which is significantly different from the other two facets, implying that it has the greatest impact on building the second-order construct (PR). Time and social risk displayed values that are almost close to each other in the building of PR; thus, it can be reported that these two types of risks have the same weight in the construction of PR construct. This implies that people are concerned about the privacy risk associated with SNSs, as compared to social and time risk. This conclusion is also similar to the findings of Featherman and Pavlou (2003), establishing that people are not as much concerned about social risk when using online sites for purchasing products.

The proposed model in Figure 1 also confirms the conclusion that PU is one of the key factors that influences an individual's attitude towards the use of SNSs for trip organisation. In addition, the two types of benefits used for this study (functional and social benefits) display values that are significantly different ( 0.90 and 0.57 , respectively). This implies that functional benefits are more important in building the second-order construct (PU) than social benefits. This means that individuals consider the functional benefits of using SNSs for trip organising more than the social benefits. This finding concurs with the findings of a previous study conducted by Lopez et al. (2011), reporting that functional benefits have the greatest impact on building PU.

The research also confirms that both $\mathrm{PBC}$ and $\mathrm{SN}$ influence one's attitude regarding the use of SNSs. This implies that if people are of the opinion that they can successfully use a particular SNS for trip organising, they will develop a positive attitude towards using the site. Similarly, advice and recommendations from close friends (SN) can also positively influence the attitude of an individual towards the use of SNSs. However, the effect of SN on attitude is moderate, 
as this is shown by a probability value of 0.05 . The possible reason might be that when using SNSs, individuals are mostly on their own; hence, the pressure from others on attitude is weaker. This finding is consistence with the findings of Akman (2014) and Hocevar et al. (2014), who also concluded that PBC is important in influencing one's attitude towards SNSs.

The research also reports that PBC influences one's intention to use SNSs with regard to travelling. When an individual perceives that he or she is capable of and certain that he or she can use SNSs for trip organising, the intention to use the sites will increase. This supports the general rule of the TPB theory, which states that when PBC is greater, the person's intention to perform behaviour becomes stronger. Results from the model proposed for this study also confirm that the attitude towards SNSs significantly influences the behavioural intention. This result is also in line with the rule of TPB, which states that the person's intention to perform behaviour becomes stronger when the attitude is more favourable. Therefore, it implies that if an individual has a positive attitude towards SNSs, he or she will be interested in using them for trip organising and will not hesitate to recommend the site to others. This is consistent with the findings of Peslak et al. (2012), Zoonen et al. (2014) and Wei et al. (2015), who postulated that the attitude towards SNSs is positively associated with the intention to use SNSs.

\section{Recommendations}

The results of the study confirm that PU exerts the greatest influence on the attitude towards the use of SNSs for trip organisation. Therefore, it is recommended that tourism destination marketers or managers must upload valuable travel information, such as the attractions found in the particular destination (through pictures or videos), how to get there (directions) as well as service offered at the destination on the social media accounts so that when travellers are seeking travel information, they can quickly access it to fulfil the functional benefit part. For example, tourism social media marketers can create a link from their Facebook or Twitter accounts to the company's website to inform travellers of services that the company can offer. Negative comments on the SNS accounts of companies should also be managed in a fast and professional manner. The reluctance to do so has the potential to instil a negative attitude towards the use of SNSs for trip organisation. A company can have a professional social media employee who is responsible for monitoring the account such that when negative comments are posted, they can be quickly attended to. One way of managing negative comments is to communicate the issue to the leadership and respond on how the matter will be rectified and remember to do it in a pleasant, positive and playful tone so that the situation is not aggravated.

PR has also a negative influence on attitude towards usage of SNSs for trip organisation. Tourism social media marketers must design and develop systems that are transparent and ensure that information found on SNSs is trustworthy. Previous studies have shown that members' PR increases when they perceive that their privacy can be abused through using online technologies (Chen 2013). It is suggested that appropriate policy should be put in place to guard against privacy breach and to avoid further abuse. It is the duty of SNS operators to ensure people's privacy online is protected in order to attract more users to the site as well as to maintain the users.

Furthermore, the results suggest that attitude is another crucial factor that affects the intention to use SNSs with regard to trip organisation. Hence, SNSs service providers should come up with ways of improving their services in order to satisfy the demands of users so that they will continue using SNSs for trip organisation. It was also found that PBC influences the attitude towards the use of SNSs, as well as the intention to use SNSs for trip organisation. Therefore, SNS service providers should ensure that all applications on SNSs are user friendly. This can be achieved through making the SNS mobile compatible, because more people are now using their mobile phones to access the Internet. If a company's SNS cannot be accessed on mobile phones, then the company has to create a mobile version of that SNS with the aid of web-based mobile website builders. SNS service providers should also ensure that there is effective navigation from one SNS feature to another.

\section{Limitations of the study}

The limitations of this study include the following: Firstly, the population of the study comprised individuals in only one province of South Africa and this might not give a true version of actual SNSs usage in South Africa. However, the results of the study received some support from previous studies; thus, generalisability might not be a problem. Therefore, it is recommended that future research should focus on a larger sample, if possible covering major towns in South Africa. Secondly, the study employed a cross-sectional approach where data were collected once and analysed. Future research may use a longitudinal approach to establish the actual use of SNSs. Because the majority of people who participated in this survey were aged between 17 and 22 years, this might not give a clear picture of how older people view the use of SNSs with regard to travelling. Future research might need to target the older age groups and a comparison can then be drawn.

\section{Conclusion}

The main aim of this study was to assess the influence of attitude and its precursors on the usage of SNSs for trip organisation. It is concluded that PU measured by functional benefits and social benefits is the key factor that influences attitude towards the use SNSs for trip organisation. It is the responsibility of destination marketers to provide all the necessary or valuable information on their SNS accounts, in order to encourage travellers to use SNSs. On the other hand, PR reduces SNSs' PU and negatively affects the attitude 
towards the use of SNSs for trip organisation. SNS service providers should put stringent measures in place. PBC and attitude both influence the intention to use SNSs. The article contributed to the existing literature by providing an extended TPB model, which can be used to analyse individuals' attitude towards the use of SNSs for trip organisation.

\section{Acknowledgements Competing interests}

The authors declare that they have no financial or personal relationships which may have inappropriately influenced them in writing this article.

\section{Authors' contributions}

R.M. was the project leader and was also responsible for methodology formulation and statistical analyses; M.M. and M.R.L made conceptual contributions.

\section{References}

Abadi, H.R.D. \& Nematizadeh, F., 2012, 'An empirical investigation of the level of users' acceptance of e-banking among some customers of banks in Iran', International Journal of Academic Research in Business and Social Sciences 2(6), 418-431.

Ajzen, I., 1988, Attitudes, personality and behaviour, Dorsey Press, Chicago.

Ajzen, I., 1991, 'The theory of planned behaviour', Organisational Behaviour and Human Decision 50(2), 179-211. http://dx.doi.org/10.1016/0749-5978(91) 90020-T

Akman, I., 2014, 'Exploring adoption of social media commerce using extended theory of planned behaviour', International Conference on Economic, Education and Humanities (ICEEH ${ }^{14}$ ), Bali, Indonesia, December 10-11.

Alam, S.S. \& Sayuti, N.M., 2011, 'Applying the theory of planned behaviour (TPB) in halal food purchasing', International Journal of Commerce and Management 21(1), 8-20. http://dx.doi.org/10.1108/10569211111111676

Al-Somali, S.A., Gholami, R. \& Clegg, B., 2009, 'An investigation into the acceptance of online banking in Saudi Arabia', Technovation 29, 130-141. http://dx.doi.org/10. 1016/j.technovation.2008.07.004

Baker, R.K. \& White, K.M., 2010, 'Predicting adolescents' use of social networking sites from an extended theory of planned behaviour perspective', Computers in Human Behaviour 26(6), 1591-1597. http://dx.doi.org/10.1016/j.chb.2010.06.006

Bauer, R., 1967, 'Consumer behavior as risk taking', in D. Cox (ed.), Risk taking and information handling in consumer behavior, pp. 23-33, Harvard University Press, Boston, MA.

Baumgartner, H. \& Hombur, C., 1996, 'Applications of structural equation modelling in marketing and consumer research: A review', International Journal of Research in Marketing 13, 139-161. http://dx.doi.org/10.1016/0167-8116(95)00038-0

Bhakuni, P. \& Aronkar, P., 2012, 'Effect of social media advertising on purchase intentions of students- An empirical study conducted in Gwalior City', International Journal of Applied Services Marketing Perspectives 1(1), 1-7.

Bhattacherjee, A., 2012, Social science research: Principles, methods, and practices textbooks collection, Book 3 , viewed 3 February 2016, from http://scholarcommons. usf.edu/oa_textbooks

Boyd, D.M. \& Ellison, N.B., 2007, 'Social network sites: Definition, history, and scholarship', Journal of Computer-Mediated Communication 13, 210-230. http:// dx.doi.org/10.1111/j.1083-6101.2007.00393.x

Cape Town Tourism, 2013, Travel and tourism (SMITTY) award, viewed 19 November 2015, from http://www.tourismbiz.co.za/press-release-details.php?id=50422

Celik, H.E. \& Yilmaz, V., 2011, 'Extending the technology acceptance model for adoption of e-shopping consumers in Turkey', Journal of Electronic Commerce Research 12(2), 152-164.

Chen, R., 2013, 'Member use of social networking sites - An empirical examination', Decision Support Systems 54(3), 1219-1227. http://dx.doi.org/10.1016/j.dss. 2012.10.028

Chin, W., 1998, 'Issues and opinions on structural equation modeling', MIS Quarterly 22(1), 7-10

Chung, J. \& Buhalis, D., 2008, 'A study on online travel community and Web 2.0: Factors affecting participation and attitude', Proceedings ENTER 2008, Innsbruck, Springer-Verlag, Wien, pp. 267-278.

Cunningham, S.J., 1976, 'The major dimension of perceived risk', in D. Cox (ed.), Risk taking and information handling in consumer behaviour, pp. 82-108, Harvard University Press, Cambridge, MA.
Davis, F.D., 1989, 'Perceived usefulness, perceived ease of use, and user acceptance of information technology', MIS Quarterly 13(3), 319-339. http://dx.doi.org/ information tech

Dennis, C., Merrilees, B., Jayawardhena, C. \& Wright, L.T., 2009, 'E-consumer behaviour', European Journal of Marketing 43(9/10), 1121-1139. http://dx.doi. org/10.1108/03090560910976393

Di Pietro, L. \& Di Virgilio, F., 2012, 'Social network for the choice of tourist destination; attitude and behaviour intention', Journal of Hospitality and Tourism Technology 3(1), 60-76. http://dx.doi.org/10.1108/17579881211206543

Featherman, M.S. \& Pavlou, P.A., 2003, 'Predicting e-service adoption: A perceived risk facets perspective', International Journal of Human-Computer Studies 59(20), 451-474. http://dx.doi.org/10.1016/S1071-5819(03)00111-3

Fishbein, M. \& Ajzen, I., 1975, Belief, attitude, intention, and behavior, AddisonWesley, Reading, MA.

Fornell, C. \& Bookstein, F.L., 1982, 'Two structural equation models: LISREL and PLS applied to consumer exit-voice theory', Journal of Marketing Research 19(4), 440-452. http://dx.doi.org/10.2307/3151718

Fornell, C. \& Larcker, D.F., 1981, 'Evaluating structural equation models with unobservable variables and measurement error', Journal of Marketing Research 18, 39-50. http://dx.doi.org/10.2307/3151312

Gong, W., 2012, 'Factors influencing perceptions towards social networking websites in China', in Proceedings Cultural Attitudes towards Technology Communication, Murdoch University Australia, Murdoch, Western Australia, pp. 420-429.

Greenleigh, I., 2012, 'Talking to strangers. How social networks influence millennials' shopping decisions', viewed 12 November 2015, from http://www.bazaarvoice. $\mathrm{com} / \mathrm{blog} / 2012 / 01 / 24 /$ infographicmillennials-willchange-the-way-you-sell/

Gretzel, U. \& Yoo, K.H., 2008, 'Use and impact of online travel reviews', Information and Communication Technologies in Tourism 2, 35-46. http://dx.doi.org/10. 1007/978-3-211-77280-5_4

Hair, J., Black, W., Babin, B. \& Anderson, R., 2010, Multivariate data analysis, 7th edn., Prentice-Hall, Inc, Upper Saddle River, NJ.

Henderson, R. \& Divett, M.J., 2003, 'Perceived usefulness, ease of use and electronic supermarket use', International Journal of Human-Computer Studies 59, 383-395. http://dx.doi.org/10.1016/S1071-5819(03)00079-X

Hocevar, K.P., Flanagin, A.J. \& Metzeger, M.J., 2014, 'Social media self-efficacy and information evaluation online', Computers in Human Behavior 39, 254-262. http://dx.doi.org/10.1016/j.chb.2014.07.020

Hoffman, D.L. \& Novak, T.P, 2012, 'Why do people use social media? Empirical findings and a new theoretical framework for social media goal Pursuit (January
$17,2012)^{\prime}$, viewed 23 November 2015, from SSRN: http://ssrn.com/ $17,2012)^{\prime}$, view
abstract $=1989586$

Hollenbeck, C.R. \& Kaikati, A.M., 2012, 'Consumers' use of brands to reflect their actual and ideal selves on Facebook', International Journal of Research in Marketing 29(4), 395-405. http://dx.doi.org/10.1016/j.ijresmar.2012.06.002

Hsu, M.H., Yen, C.H., Chiu, C.M. \& Chang, C.M., 2006, 'A longitudinal investigation of continued online shopping behaviour: An extension of the theory of planned behaviour' International Journal of Human Computer Studies 64(9), 889-904. $\mathrm{http} / / / \mathrm{dx}$.doi.org/10.1016/j.ijhcs.2006.04.004

$\mathrm{Hu}, \mathrm{L}$. \& Bentler, P.M., 1999, 'Cut off criteria for fit indexes in covariance structure analysis: Conventional criteria versus new alternatives', Structural Equation Modelling 6(1), 1-55. http://dx.doi.org/10.1080/10705519909540118

Jalilvand, M.R. \& Samiei, N., 2012, 'The electronic word of mouth on a tourism destination. Testing the theory of planned behaviour (TPB)', Internet Research 22(5), 591-612. http://dx.doi.org/10.1108/10662241211271563

Jeong, S., 2008, 'Collective production of public good in online travel communities' Information Technology \& Tourism 10(4), 355-373. http://dx.doi.org/10.3727/ 109830508788403141

Kemp, S., 2015, Digital, social \& mobile in 2015, viewed 21 January 2016, from http:// wearesocial.com/uk/special-reports/digital-social-mobile-worldwide-2015

Lange-Faria, W. \& Elliot, S., 2012, 'Understanding the role of social media in destination marketing', An International Multidisciplinary Journal of Tourism 7(1), 193-211.

Leng, G.S., Lada, S., Muhammad, M.Z., Ibrahim, A. \& Amboala, T., 2011, 'An exploration of social networking sites (SNS) adoption in Malaysia using Technology Acceptance Model (TAM), Theory of Planned Behavior (TPB) and Intrinsic Motivation', Journal Model (TAM), Theory of Planned Behavior (TPB).
of Internet Banking and Commerce 16(2), 1-27.

Lopez, E.P., Bulchand-Gidumal, J., Tano, D.G. \& Armas, R.J.D., 2011, 'Intentions to use social media in organising and taking vacation trips', Computers in Human Behaviour 27(2), 640-654. http://dx.doi.org/10.1016/j.chb.2010.05.022

Lopez-Nicolas, C., Molina-Castillo, F.J. \& Bouwman, I., 2008, 'An assessment of advanced mobile services acceptance: Contributions from TAM and diffusion theory models', Information and Management 45(6), 359-364. http://dx.doi. org/10.1016/j.im.2008.05.001

Lyu, S.O. \& Wang, J., 2015, 'Are the days of information centres gone? Effects of the ubiquitous information availability', Tourism Management 48, 54-63. http://dx. doi.org/10.1016/j.tourman.2014.11.001

Mannuka, J. \& Jarvi, P., 2014, 'Perceived risks and risk management of social media in an organisational context', Electron Markets 24, 219-229. http://dx.doi. org/10.1007/s12525-013-0138-2

Marshal, M.N., 1996, 'Sampling for qualitative research', Family Practice 13(6), 522-525. http://dx.doi.org/10.1093/fampra/13.6.522

Martin, D.S., Ramamonjiarivelo, Z. \& Martin, W.S., 2011, 'MEDTOUR: A scale for measuring medical tourism intentions', Tourism Review 66(1/2), 45-56. http:// dx.doi.org/10.1108/16605371111127233 
Pelling, E. \& White, K.M., 2009, 'The theory of planned behaviour applied to young people's social networking websites', Cyber Psychology and Behaviour 12, 755759. http://dx.doi.org/10.1089/cpb.2009.0109

Peslak, A., Ceccucci, W. \& Sendall, P., 2012, 'An empirical study of social networking behaviour using Theory of Reasoned Action', Journal of Information System Applied Research 5(3), 12-23. http://jisar.org/2012-5/ISSN: 1946-1836

Peter, J. \& Ryan, M., 1976, 'An investigation of perceived risk at the brand level', Journal of Marketing Research 13, 184-188. http://dx.doi.org/10.2307/3150856

Porter, C.E. \& Donthu, N., 2006, 'Using technology acceptance model to explain how attitudes determine internet usage. The role of perceived access barriers and demographics', Journal of Business Research 59, 999-1007. http://dx.doi.org/10. 1016/j.jbusres.2006.06.003

Quintal, V.B., Lee, J.A. \& Soutar, J.N., 2010, 'Risk, uncertainty of the theory of planned behaviour. A tourism example', Tourism Management 31(6), 797-805. http://dx. doi.org/10.1016/j.tourman.2009.08.006

Rauniar, R., Rawski, G., Yang, J. \& Johnson, B., 2014, 'Technology acceptance mode and social media usage: An empirical study on Facebook', Journal of Enterprise Information Management 27(1), 6-30. http://dx.doi.org/10.1108/JEIM-04-2012 0011

Richard, J.E. \& Guppy, S., 2014, 'Facebook: Investigating the influence on consumer purchase intention', Asian Journal of Business Research 4(2), 1-10. http://dx.doi. purchase intention', Asian
org/10.14707/ajbr.140006

Roselius, T., 1971, 'Consumer rankings of risk reduction methods', The Journal of Marketing 35(1), 56-61. http://dx.doi.org/10.2307/1250565

Schumacker, R.E. \& Lomax, R.G., 2004, A beginner's guide to structural equation modelling, 2nd edn., Lawrence Erlbaum Associates, Mahwah, NJ.

Senthil, M., Prabhu, N.R.V. \& Bhuvaneswari, S., 2013, 'Customers' perception toward advertising in the online shopping and social networking websites among Internet users in India', AMET, International Journal of Management 2(1), 50-59.

Sentosa, I. \& Nik Mat, N.K., 2012, 'Examining the theory of planned behaviour (TPB) in internet purchasing using structural equation modelling', International Refereed Research Journal 3(2), 62-77.

Sheeran, P., Orbell, S. \& Trafimow, D., 1999, 'Does the temporal stability of behaviora intentions moderate intention-behavior and past behavior-future behavior relations?', Personality and Social Psychology Bulletin 25, 721-730. http://dx.doi. org/10.1177/0146167299025006007

Sigala, M., 2010, 'Measuring customer value in online collaborative trip planning process', Marketing Intelligence and Planning 28(4), 418-443. http://dx.doi.org/ 10.1108/02634501011053559

Singh, N., Lehnert, K. \& Bostick, K., 2012, 'Global social media usage: Insights into reaching consumers worldwide', Thunderbird International Business Review 54(5), 684-695. http://dx.doi.org/10.1002/tie.21493
Skarmeas, D. \& Robson, M., 2008, 'Determinants of relationship quality in importerexporter relationship', British Journal of Management 19(2), 171-184, http://dx. doi.org/10.1111/j.1467-8551.2007.00537.x

South Africa Social Media Landscape, 2015, 'Facebook bridges South Africa gender divide', viewed 20 October 2015, from http://www.worldwideworx.com/wpcontent

South African Tourism Review, 2015, 'Report of the expert panel to Minister Hanekom', viewed 28 January 2016, from http://www.tourism.gov.za/AboutNDT/ Publications/Final\%20report $\% 20$ of $\% 20$ the $\% 20$ SA $\% 20$ Tourism $\% 20$ Review $\% 20$ June $\% 202015$

Statista, 2015, 'Leading social networks worldwide as of January 2016, ranked by number of active users (in millions)', viewed 3 February 2016, from http://www. statista.com/statistics/272014/global-social-networks-ranked-by-number-ofusers

TripAdvisor, 2015, 'Fact sheet-TripAdvisor', viewed 20 October 2015, from http:// www.tripadvisor.com/PressCentre-c4-fact-sheet

Troung, Y., 2009, 'An evaluation of the theory of planned behaviour in consumer acceptance of online video and television services', The Electronic Journal of Information Systems Evaluation 12(2), 177-186.

Wei, H.L., Lin, K.Y., Lu, H.P. \& Chuang, I.H., 2015, 'Understanding the intentions of users to "stick" to social networking sites: A case study in Taiwan', Behavioural and Information Technology 34(2), 151-162. http://dx.doi.org/10.1080/0144929X. 2014.928745

Wetzels, M., Odekerken-schroder, G. \& Van Oppen, C., 2009, 'Using PLS path modelling for assessing hierarchical construct models. Guidelines and empirical illustrations', MIS Quarterly 33(1), 177-195.

Xiang, Z. \& Gretzel, U., 2010, 'Role of social media in online travel information search', Tourism Management 31(2), 179-188. http://dx.doi.org/10.1016/j.tourman.2009. 02.016

Yzer, M., 2012, 'Perceived behavioural control in reasoned action theory: A dual Aspect interpretation', The Annals of the American Academy of Political \& Social Sciences 640, 101-117. http://dx.doi.org/10.1177/0002716211423500

Zhou, T., 2011, 'Understanding online community user participation: A social influence perspective', Internet Research 21(1), 68-81. http://dx.doi.org/10.1108/106622 41111104884

Ziadat, M.T., 2015, 'Applications of planned behavior theory (TPB) in Jordanian Tourism', International Journal of Marketing Studies 7(3), 95-106. http://dx.doi. org/10.5539/ijms.v7n3p95

Zikmund, W.G., 1984, Business research methods, 18th edn., Dryden Press, Chicago, IL.

Zoonen, W., Verhoeven, J.W.H. \& Elving, W.J.L., 2014, 'Understanding work related social media use: An extension of the theory of planned behaviour', International Journal of Management, Economics and Social Sciences 3(4), 164-183. 


\section{APPENDIX 1}

TABLE 1-A1: Operationalisation of constructs.

\begin{tabular}{|c|c|c|}
\hline Item & Measurement & References \\
\hline \multicolumn{3}{|c|}{ Perceived risk } \\
\hline \multirow[t]{3}{*}{ Social risk } & Using social networking sites negatively affects the way others think about you & \multirow{3}{*}{$\begin{array}{l}\text { Featherman and Pavlou (2003); Quintal et al. } \\
\text { (2010); } \\
\text { Mannuka and Jarvi (2014). }\end{array}$} \\
\hline & $\begin{array}{l}\text { Signing up for using social networking sites would lead one to a social loss because } \\
\text { friends would think less highly of you }\end{array}$ & \\
\hline & $\begin{array}{l}\text { Using social networking sites may result in loss of people close to you who have a } \\
\text { negative attitude towards them }\end{array}$ & \\
\hline \multirow[t]{3}{*}{ Privacy risk } & $\begin{array}{l}\text { The use of social networking sites can cause one to lose control of the privacy of } \\
\text { personal information }\end{array}$ & \multirow[t]{3}{*}{$\begin{array}{l}\text { Featherman and Pavlou (2003); Quintal et al. } \\
\text { (2010). }\end{array}$} \\
\hline & $\begin{array}{l}\text { Internet hackers are likely to take control of one's account and use one's personal } \\
\text { information }\end{array}$ & \\
\hline & $\begin{array}{l}\text { Use of social networking sites can result in one personal information to be used } \\
\text { without their knowledge }\end{array}$ & \\
\hline \multirow[t]{3}{*}{ Time risk } & Use of social networking sites results in loss of time & \multirow{3}{*}{$\begin{array}{l}\text { Featherman and Pavlou (2003); Mannuka and Jarvi } \\
\text { (2014); } \\
\text { Quintal et al. (2010) }\end{array}$} \\
\hline & Use of social networking sites is time demanding & \\
\hline & $\begin{array}{l}\text { Use of social networking sites requires considerable investment in time especially } \\
\text { when learning how to use the site }\end{array}$ & \\
\hline
\end{tabular}

\section{Perceived benefits}

Functional

benefits

Social networking sites enable one to keep up to date with knowledge about interesting trips

Lopez et al. (2011).

Social networking sites give the possibility to provide and to receive information about attractions of interest

Social networking sites allow one to save cost when searching for travel information

Social

benefits

Social networking sites allow one to stay in contact with friends who share the same interests regarding tourist destination

Social networking sites provide one with a strong feeling of belonging to a group

Through the use of social networking sites, one's personal relationship with friends of similar interest regarding travelling increases

Attitude

I am positive towards the use of social networking sites for trip organisation It makes sense to use social networks when planning and organising a trip

Overall, my attitude towards social networking sites for trip organisation is positive

I like the idea of using social networking sites for trip organisation

I think the idea of using social networking sites for trip organisation is wise

Subjective

norm

Perceived behavioura control

Intention to use social networking sites

Intention to recommend
Most people close to me think I should use social networking sites when planning and organising a trip

People whom I trust recommend me to use social networking sites when planning and organising trips

Other people I know expect that people like me should use social networking sites when planning and organising trips

People whose opinion I value would prefer me to use social networking sites when planning and organising trips

I can easily use social networking sites when planning and organising trips

I have the knowledge and ability to use social networking sites to search for travel information

I am confident that I can use social networking sites for planning and organising trips I am confident that I can successfully use social networking sites to organise a trip If I want to use social networking sites to organise trips, it would be easy I plan to use social networking sites when planning and organising trips I intend to use social networking sites in planning and organising trips in the future I predict I will use social networking sites for trip organisation

I am sure that I will use social networking sites to search for travel information

I will recommend others to use social networking sites for trip organisation

I will encourage my friends to use social networking sites for trip organisation

I will tell others about the benefits of social networking sites when planning and organising trips
Lopez et al. (2011).

Pelling and White (2009); Porter and Donthu (2006); Ziadat (2015).

Lopez et al. (2011).

Jalivand and Samiei (2012);

Sheeran, Orbell and Trafimow (1999).

Al-somali et al. (2009).

Al-somali et al. (2009).

Source: Researcher's compilation from the existing literature 
TABLE 2-A1: Partial Least Squares (PLS) item cross-correlation.

\begin{tabular}{|c|c|c|c|c|c|c|c|c|c|c|}
\hline & $\begin{array}{c}\text { Social } \\
\text { risk (SR) }\end{array}$ & $\begin{array}{l}\text { Time } \\
\text { risk (TR) }\end{array}$ & $\begin{array}{l}\text { Privacy } \\
\text { risk (PR) }\end{array}$ & $\begin{array}{c}\text { Functional } \\
\text { benefits (FB) }\end{array}$ & $\begin{array}{l}\text { Social benefits } \\
\text { (SB) }\end{array}$ & $\begin{array}{l}\text { Subjective } \\
\text { norm (SN) }\end{array}$ & $\begin{array}{c}\text { Perceived } \\
\text { behavioural } \\
\text { control (PBC) }\end{array}$ & $\begin{array}{l}\text { Attitude } \\
\text { (ATT) }\end{array}$ & $\begin{array}{l}\text { Intention to } \\
\text { use (Int) }\end{array}$ & $\begin{array}{l}\text { Intention to } \\
\text { recommend } \\
\text { (Int R) }\end{array}$ \\
\hline SR1 & 0.80 & 0.14 & 0.22 & 0.00 & -0.03 & 0.18 & 0.10 & -0.08 & -0.12 & -0.01 \\
\hline SR2 & 0.82 & 0.19 & 0.18 & -0.02 & -0.10 & 0.21 & 0.07 & -0.10 & -0.09 & -0.03 \\
\hline SR3 & 0.78 & 0.22 & 0.25 & -0.04 & -0.12 & 0.19 & 0.05 & -0.09 & -0.07 & -0.01 \\
\hline TR1 & 0.21 & 0.85 & 0.14 & -0.01 & -0.01 & 0.16 & 0.04 & -0.01 & -0.01 & -0.04 \\
\hline TR2 & 0.32 & 0.82 & 0.09 & -0.05 & -0.02 & 0.09 & 0.09 & -0.03 & -0.02 & -0.01 \\
\hline TR3 & 0.15 & 0.94 & 0.12 & -0.02 & -0.02 & 0.08 & 0.04 & -0.06 & -0.01 & -0.05 \\
\hline PR1 & 0.14 & 0.11 & 0.86 & -0.11 & -0.09 & 0.03 & 0.00 & -0.18 & -0.18 & -0.10 \\
\hline PR2 & 0.23 & 0.15 & 0.90 & -0.16 & -0.08 & 0.00 & -0.01 & -0.23 & -0.22 & -0.13 \\
\hline PR3 & 0.17 & 0.18 & 0.94 & -0.18 & -0.12 & 0.04 & 0.02 & -0.29 & -0.28 & -0.15 \\
\hline FB1 & 0.00 & -0.01 & -0.14 & 0.94 & 0.08 & 0.23 & 0.13 & 0.39 & 0.27 & 0.19 \\
\hline FB2 & -0.03 & -0.09 & -0.21 & 0.89 & 0.21 & 0.19 & 0.10 & 0.28 & 0.31 & 0.21 \\
\hline FB3 & -0.04 & -0.07 & -0.08 & 0.86 & 0.16 & 0.16 & 0.12 & 0.37 & 0.27 & 0.31 \\
\hline SB1 & -0.10 & 0.00 & -0.12 & 0.15 & 0.89 & 0.21 & 0.08 & 0.21 & 0.18 & 0.19 \\
\hline SB2 & -0.09 & -0.01 & -0.15 & 0.18 & 0.84 & 0.14 & 0.14 & 0.26 & 0.21 & 0.21 \\
\hline SB3 & -0.12 & -0.05 & -0.10 & 0.10 & 0.90 & 0.22 & 0.17 & 0.29 & 0.16 & 0.17 \\
\hline SB4 & -0.14 & 0.00 & -0.13 & 0.19 & 0.88 & 0.19 & 0.11 & 0.25 & 0.20 & 0.12 \\
\hline SN1 & 0.17 & 0.12 & 0.04 & 0.08 & 0.21 & 0.86 & 0.15 & 0.17 & 0.14 & 0.10 \\
\hline SN2 & 0.10 & 0.04 & 0.08 & 0.13 & 0.31 & 0.91 & 0.03 & 0.21 & 0.16 & 0.13 \\
\hline SN3 & 0.15 & 0.11 & 0.12 & 0.06 & 0.28 & 0.90 & 0.04 & 0.28 & 0.16 & 0.13 \\
\hline PBC1 & 0.09 & 0.03 & 0.01 & 0.11 & 0.23 & 0.13 & 0.89 & 0.33 & 0.21 & 0.21 \\
\hline PBC2 & 0.10 & 0.05 & 0.04 & 0.13 & 0.19 & 0.10 & 0.92 & 0.25 & 0.25 & 0.16 \\
\hline PBC3 & 0.00 & -0.03 & -0.01 & 0.16 & 0.24 & 0.17 & 0.86 & 0.20 & 0.23 & 0.21 \\
\hline PBC4 & -0.01 & 0.01 & 0.00 & 0.17 & 0.20 & 0.19 & 0.80 & 0.27 & 0.29 & 0.30 \\
\hline PBC5 & 0.07 & -0.04 & 0.07 & 0.10 & 0.14 & 0.21 & 0.87 & 0.29 & 0.32 & 0.15 \\
\hline ATT1 & -0.04 & -0.02 & -0.21 & 0.40 & 0.23 & 0.28 & 0.31 & 0.91 & 0.38 & 0.21 \\
\hline ATT2 & -0.10 & -0.08 & -0.31 & 0.36 & 0.31 & 0.18 & 0.29 & 0.87 & 0.33 & 0.27 \\
\hline ATT3 & -0.09 & -0.12 & -0.28 & 0.32 & 0.25 & 0.28 & 0.33 & 0.84 & 0.28 & 0.32 \\
\hline ATT4 & -0.13 & -0.09 & -0.33 & 0.30 & 0.19 & 0.21 & 0.27 & 0.88 & 0.37 & 0.29 \\
\hline ATT5 & -0.01 & -0.03 & -0.29 & 0.33 & 0.27 & 0.19 & 0.21 & 0.90 & 0.40 & 0.21 \\
\hline INT1 & -0.03 & -0.01 & -0.11 & 0.27 & 0.28 & 0.17 & 0.19 & 0.40 & 0.87 & 0.23 \\
\hline INT2 & -0.14 & -0.06 & -0.22 & 0.20 & 0.23 & 0.14 & 0.14 & 0.38 & 0.78 & 0.32 \\
\hline INT3 & -0.11 & -0.09 & -0.27 & 0.19 & 0.21 & 0.16 & 0.21 & 0.39 & 0.91 & 0.14 \\
\hline INT4 & -0.06 & -0.10 & -0.20 & 0.09 & 0.30 & 0.19 & 0.23 & 0.29 & 0.90 & 0.14 \\
\hline INTR1 & -0.02 & -0.02 & -0.10 & 0.08 & 0.16 & 0.09 & 0.10 & 0.21 & 0.21 & 0.92 \\
\hline INTR2 & -0.01 & -0.01 & -0.15 & 0.11 & 0.13 & 0.12 & 0.15 & 0.31 & 0.19 & 0.86 \\
\hline INTR3 & 0.00 & -0.05 & -0.16 & 0.13 & 0.21 & 0.10 & 0.09 & 0.17 & 0.26 & 0.83 \\
\hline
\end{tabular}

